\title{
A Suicidal Kuznets Curve?
}

\author{
Nikolaos Antonakakis*† Alan Collins ${ }^{\ddagger}$
}

\begin{abstract}
Suicide rates from a global sample of 73 countries over the period 1990-2010 are empirically explored. We find evidence of an ' $\mathrm{N}$-shaped' suicidal Kuznets curve between per capita income and suicide rates in the male population of 25-34, 34-54 and 55-74 age groups and the female population of the 55-74 age group. These results remain firm to several robustness checks.
\end{abstract}

Key words: Suicide; GDP growth; Kuznets curve; Unemployment; Fertility; Life expectancy

JEL codes: C33, E32, I15, I31, J13

${ }^{*}$ Corresponding author: Webster Vienna University, Department of Business and Management, Praterstrasse 23, 1020, Vienna, Austria tel: +43 12699293 4354, e-mail: nikolaos.antonakakis@webster.ac.at.

${ }^{\dagger}$ University of Portsmouth, Economics and Finance Subject Group, Portsmouth Business School, Portland Street, Portsmouth, PO1 3DE, United Kingdom Tel: +44 (0)23 9284 4261, fax: +44 (0)23 9284 4037, e-mail: nikolaos.antonakakis@port.ac.uk

${ }^{\ddagger}$ Nottingham Trent University, Department of Economics, Nottingham Business School, 50 Shakespeare Street, NG1 4FQ, Nottingham, United Kingdom, e-mail: alan.collins@ntu.ac.uk. 


\section{Introduction}

Suicide rates are an indicator of extreme life dissatisfaction and constitute a negative revealed preference indicator of well-being within a given country. This remains contentious given some medical researchers caution against inferring broader societal mental health conditions from suicide rates (Holley, 1998). However, if the focus is on inferring more narrowly across suicidal ideation and chronic depression, then such inference is reasonable.

The well-being and specifically mental health effects of variations in socioeconomic factors have received enormous empirical attention. One particular aspect, the linkage between suicide mortality and unemployment, has prompted much discussion in recent decades (see, for example, Antonakakis and Collins, 2014, 2015) and there is a sizeable literature on the link to other socioeconomic indicators, such as income and/or economic growth (see, for example, Hamermesh and Soss, 1974; Virén, 1999; Jungeilges and Kirchgassner, 2002; Andrés, 2005; Okada and Samreth, 2013). Despite the breadth and depth of existing work, no study to our best knowledge examines in a systematic fashion the global pattern of well-being via a revealed preference approach and with a particular focus on the suicide-income (growth) relationship.

Economic prosperity has been postulated in various works to lead to both declines and rises in suicide mortality.This is reflected by mixed evidence in empirical work. For example, Virén (1999) and Jungeilges and Kirchgassner (2002) suggest that suicide rates have a positive association with income while there are many others suggesting the opposite effect (e.g. Andrés et al., 2011; Okada and Samreth, 2013) or insignificant results. Against this backdrop, we examine whether suicide mortality differs with respect to socio-demographic factors and the level of economic development among countries. Put differently, we investigate the existence or otherwise of a 'suicidal Kuznets curve' (SKC). We find evidence of an N-shaped suicidal Kuznets curve between per capita income and suicide rates in the male population of 25-34, 34-54 and 55-74 age groups and the female population of the 55-74 age group.

The remainder of this paper is organised as follows. Section 2, outlines the methodology and describes the data used. Section 3 presents the empirical results and Section 4 summarises and offers some concluding remarks. 


\section{Data and Methodology}

Annual observations of gender- and age-specific suicide and population data were extracted from the World Health Organization (WHO) Mortality Database. Missing values of suicide and population were supplemented (where possible) with data from the official national statistics agency of each country and United Nations statistics. Following inspection of the data series we settled on a panel dataset of 73 countries covering the period 1990 to 2010. The choice of specific countries and time periods was driven by data availability. For a detailed data description, please refer to the Online Appendix.

Following earlier literature (see Chen et al., 2012), we additionally control for the potential socioeconomic determinants of suicide rates across countries. We estimated variants of the following (extended) Suicidal Kuznets curve model:

$$
S_{i j k t}=\alpha_{0}+\alpha_{1} S_{i j k t-1}+\beta_{1} Y_{i t}+\beta_{2} Y_{i t}^{2}+\beta_{3} Y_{i t}^{3}+\beta_{4} E_{i t}+\beta_{5} D_{i t}+\gamma_{i}+\delta_{t}+\varepsilon_{i t}
$$

where $S_{i j k t}$ is the suicide rate in country $i$ (where $i=1,2, \ldots, 73$ ), population $j$ (where $j=$ overall, male, female), age group $k$ (where $k=$ all, 15-24, 25-34, 35-54, 55-74, 75+ years) and time $t$ (where $t=1990, \ldots, 2010) ; \alpha_{0}$ is a constant; $S_{i j k t-1}$ is the first lag of $S_{i j k t}$ and is included to account for dynamic effects and to filter autocorrelation of order one, $\mathrm{AR}(1)$, found in the series; $Y_{i t}, Y_{i t}^{2}$ and $Y_{i t}^{3}$ denote the logarithm of real per capita GDP (at purchasing power parity, PPP, rates; 2011 US\$) in level, square and cubic terms, respectively; $E_{i t}$ is a vector of economic characteristics affecting suicide rates, such as the growth rate of real GDP, Growth $h_{i t}$, and the unemployment rate, $U n e m p_{i j t} ; D_{i t}$ is a vector of demographic and social characteristics affecting suicide rates, such as fertility rate, Fert ${ }_{i t}$, life expectancy, Lifexp $\operatorname{ext}_{i j t}$ and the share of urban population, Urban $n_{i t} \cdot \gamma_{1 i}$ are country fixed-effects controlling for time-invariant country characteristics, and $\delta_{t}$ are time fixed-effects, controlling for any time-varying differences in the dependent variable common to all countries, such as the global financial crisis. $\varepsilon_{i t}$ is the error term.

However, the inclusion of the lagged dependent variable, $S_{i j k t}$ gives rise to 'dynamic panel bias', and any potential endogeneity of the right hand side variables, may give rise to inconsistent estimates under the fixed effects (FE) estimator. To overcome these issues, we employ the system generalised method of moments (System-GMM) estimator approach. 
Moreover, we used the two-step rather than the one-step approach, as the former is asymptotically more ecient than the latter and is robust to substantial heteroskedasticity and autocorrelation within panels. The inclusion of the logarithm of per capita GDP in level, $Y_{t}$, square, $Y_{t}^{2}$, and cubic, $Y_{t}^{3}$, terms in model (1) serves as our primary focus in the examination of the potential relationship between suicide rates and economic development, i.e. the SKC. The existence and shape of such a curve depends on the significance and signs of the coefficients $\beta_{1}, \beta_{2}$ and $\beta_{3}$ from model (1).

\section{Estimation Results}

The main results of our empirical analysis for male and female populations, across the various age groups, are reported in Tables 1 to $2 .^{1}$ There is evidence of gender- and age-specificity in the relationship between suicide rates and economic development. We observe that, generally, the coefficients of per capita income, including squared and cubic counterparts are positive, negative and positive, respectively, across males of all ages in Table 1. Yet, they are only significant for the 25-34 (at the 10\% level), 35-54 (at the 5\% level) and 55-74 (at the 10\% level) age groups, under columns (3), (4) and (5) of Table 1, respectively. This is suggestive of the existence of an $N$-shaped Suicidal Kuznets curve in the case of the aforementioned age groups of the male population. Further, the validity of our instruments is strongly supported, as the autocorrelation tests of order 1 and 2 in the first-differenced residuals of the GMM approach point to first-order but not secondorder autocorrelation, as one would expect. Turning to the female population results reported in Table 2, an $N$-shaped SKC is identified for females in the 55-74 age group under column (5) of Table 2. Further our model appears correctly specified, as the results of the autocorrelation tests provide strong support to the validity of our instruments.

[Insert Tables 1 and 2 around here]

The $N$-shaped SKCs empirically identified are in line with an assessment of the corresponding scatter plots (not presented herein, but available from authors upon request). Further, our empirical results suggest that a significant $N$-shaped SKC exists only for

\footnotetext{
${ }^{1}$ The results for the overall population are available in the Online Appendix.
} 
the female population in the 55-74 age group. The results for the remaining predictors of suicide mortality accounted for are in line with the existing literature and are significant in many instances. Yet, there is also evidence of gender- and age- heterogeneity in the responses of suicides rates to those predictors.

Having found evidence of an N-shaped SKC for the identified age groups we calculated the inflection points (for calculation details, please refer to the Online Appendix). The inflection points are presented in Table 3. For the male population of 25-34, 34-54 and 5574 age groups these are $\$ 7,727$ and $\$ 46,306, \$ 5,266$ and $\$ 22,726$, and $\$ 3,459$ and $\$ 53,260$, respectively, while for the female population of 5574 age groups are $\$ 4,022$ and $\$ 43,351$. On average and across both genders, as per capita income increases, suicide rates for the 25-34 and 35-54 age groups follow an increasing trend and peak when per capita income reaches $\$ 7,304$ and $\$ 6,498$, respectively, then follow a declining trend until $\$ 60,819$ and $\$ 25,129$, respectively, and increase thereafter again.

\section{[Insert Table 3 around here]}

Finally, the aforementioned results are very robust to various robustness checks presented in the Online Appendix.

\section{Summary and Concluding Discussion}

Intuitively it appears from these results that the race to increase income over time in order to escape poverty generates net negative mental health spillover effects. Then for middleincome countries, any further income rises are seemingly associated with net positive mental health spillover effects. For high-income group countries, further income increases seem to be associated again with net negative mental health spillover effects. It seems likely, however, that there are a different or wider range of factors (compared to the lowincome countries) that account for these net negative mental health spillover effects which further research might help identify e.g. work-life balance concerns, arduous commuting, peer group pressures and status anxieties that echo elements of the Duesenberry (1949) relative income hypothesis. 
Exploring the link between economic development and well-being via this revealed preference methodology has uncovered some robust evidence of SKCs. Controlling for several country-specific suicide determinants, we show evidence of an $N$-shaped SKC both in the male population (within the 25-34, 34-54 and 55-74 age groups) and female population (in the 55-74 age group).

These results goes some way to account for the degree of plurality in the existing body of empirical findings on the suicide-economic growth linkage. The results may also serve as evidence to prompt some countries, in the face of declining suicide rates, to guard against complacency if increased economic prosperity is anticipated. Given the N-shaped form of the relationship there is a case for resisting very significant diminution of resources devoted to encouraging mental health wellbeing and addressing suicidal behaviour.

\section{References}

Andrés, A. R., 2005. Income Inequality, Unemployment, and Suicide: A Panel Data Analysis of 15 European Countries. Applied Economics 37 (4), 439-451.

Andrés, A. R., Halicioglu, F., Yamamura, E., 2011. Socio-economic Determinants of Suicide in Japan. Journal of Behavioral and Experimental Economics 40 (6), 723-731.

Antonakakis, N., Collins, A., 2014. The Impact of Fiscal Austerity on Suicide: On the Empirics of a Modern Greek Tragedy. Social Science \&6 Medicine 112, 39-50.

Antonakakis, N., Collins, A., 2015. The Impact of Fiscal Austerity on Suicide Mortality: Evidence Across the Eurozone 'Periphery'. Social Science \& Medicine 145, 63-78.

Bond, S. R., 2002. Dynamic Panel Data Models: A Guide to Micro Data Methods and Practice. Portuguese Economic Journal 1 (2), 141-162.

Brainerd, E., 2001. Economic Reform and Mortality in the Former Soviet Union: A Study of the Suicide Epidemic in the 1990s. European Economic Review 45 (4-6), 1007-1019.

Chen, J., Choi, Y. J., Mori, K., Sawada, Y., Sugano, S., 2012. Socio-Economic Studies On Suicide: A Survey. Journal of Economic Surveys 26 (2), 271-306. 
Duesenberry, J. S., 1949. Income, Saving and the Theory of Consumer Behaviour. Cambridge, MA: Harvard University Press.

Hamermesh, D. S., Soss, N. M., 1974. An Economic Theory of Suicide. Journal of Political Economy $82(1), 83-98$.

Holley, H., 1998. Geography and Mental Health: A Review. Social Psychiatry and Psychiatric Epidemiology 33 (11), 535-542.

Jungeilges, J., Kirchgassner, G., 2002. Economic Welfare, Civil Liberty, and Suicide: An Empirical Investigation. Journal of Socio-Economics 31 (3), 215-231.

Nickell, S. J., 1981. Biases in Dynamic Models with Fixed Effects. Econometrica 49 (6), $1417-1426$.

Okada, K., Samreth, S., 2013. A study on the Socio-economic Determinants of Suicide: Evidence from 13 European OECD Countries. Journal of Behavioral and Experimental Economics 45 (C), 78-85.

Virén, M., 1999. Testing the "Natural Rate of Suicide" Hypothesis. International Journal of Social Economics 26 (12), 1428-1440. 
Table 1: $N$-shaped Suicidal Kuznets Curve? Male population

\begin{tabular}{|c|c|c|c|c|c|c|}
\hline & $(1)$ & $(2)$ & $(3)$ & $(4)$ & $(5)$ & $(6)$ \\
\hline & all & $15-24$ & $25-34$ & $35-54$ & $55-74$ & $75+$ \\
\hline Lagged Dep. Var. & $\begin{array}{c}0.9853^{* * *} \\
(0.0351)\end{array}$ & $\begin{array}{c}0.4552^{* * *} \\
(0.0780)\end{array}$ & $\begin{array}{c}0.4725^{* * *} \\
(0.1320)\end{array}$ & $\begin{array}{c}0.9074^{* * *} \\
(0.0414)\end{array}$ & $\begin{array}{c}0.7232^{* * *} \\
(0.0924)\end{array}$ & $\begin{array}{c}0.4893^{* * *} \\
(0.0935)\end{array}$ \\
\hline Per Capita Income & $\begin{array}{c}61.5332 \\
(40.9405)\end{array}$ & $\begin{array}{c}10.4950 \\
(75.1504)\end{array}$ & $\begin{array}{l}277.9982^{*} \\
(153.0956)\end{array}$ & $\begin{array}{c}246.8616^{* *} \\
(119.1554)\end{array}$ & $\begin{array}{l}232.6048^{*} \\
(137.3880)\end{array}$ & $\begin{array}{l}-190.9893 \\
(283.0908)\end{array}$ \\
\hline Per Capita Income ${ }^{2}$ & $\begin{array}{l}-6.8394 \\
(4.3601)\end{array}$ & $\begin{array}{l}-0.3670 \\
(8.1897)\end{array}$ & $\begin{array}{c}-28.4649^{*} \\
(16.2027)\end{array}$ & $\begin{array}{c}-26.7090^{* *} \\
(12.6851)\end{array}$ & $\begin{array}{c}-24.9591^{*} \\
(14.6648)\end{array}$ & $\begin{array}{c}23.0303 \\
(31.2001)\end{array}$ \\
\hline Per Capita Income ${ }^{3}$ & $\begin{array}{c}0.2520^{*} \\
(0.1531)\end{array}$ & $\begin{array}{l}-0.0081 \\
(0.2959)\end{array}$ & $\begin{array}{c}0.9635^{*} \\
(0.5698)\end{array}$ & $\begin{array}{c}0.9573^{* *} \\
(0.4451)\end{array}$ & $\begin{array}{c}0.8743^{*} \\
(0.5168)\end{array}$ & $\begin{array}{c}-0.8903 \\
(1.1341)\end{array}$ \\
\hline Growth & $\begin{array}{c}-8.2030^{* *} \\
(3.2233)\end{array}$ & $\begin{array}{l}-2.4913 \\
(1.6648)\end{array}$ & $\begin{array}{l}-7.7748 \\
(5.2864)\end{array}$ & $\begin{array}{c}-17.1962^{* *} \\
(7.6698)\end{array}$ & $\begin{array}{c}-13.0094^{*} \\
(6.9517)\end{array}$ & $\begin{array}{c}-6.3905 \\
(6.8996)\end{array}$ \\
\hline Unemployment & $\begin{array}{c}0.0267 \\
(0.0390)\end{array}$ & $\begin{array}{c}0.1349^{* *} \\
(0.0645)\end{array}$ & $\begin{array}{c}0.2054^{* *} \\
(0.0961)\end{array}$ & $\begin{array}{c}0.0079 \\
(0.0839)\end{array}$ & $\begin{array}{c}0.0509 \\
(0.0871)\end{array}$ & $\begin{array}{c}0.0669 \\
(0.1462)\end{array}$ \\
\hline Fertility & $\begin{array}{c}-0.9209^{* *} \\
(0.4328)\end{array}$ & $\begin{array}{c}-2.9390^{* * *} \\
(0.8679)\end{array}$ & $\begin{array}{c}-2.9054^{* *} \\
(1.4062)\end{array}$ & $\begin{array}{c}-1.9080^{* * *} \\
(0.7194)\end{array}$ & $\begin{array}{c}-2.8069^{*} \\
(1.4729)\end{array}$ & $\begin{array}{l}-2.8918 \\
(3.1257)\end{array}$ \\
\hline Life Expectancy & $\begin{array}{l}-0.1310 \\
(0.1215)\end{array}$ & $\begin{array}{c}-0.5338^{* * *} \\
(0.1742)\end{array}$ & $\begin{array}{c}-1.0843^{* * *} \\
(0.3866)\end{array}$ & $\begin{array}{l}-0.3375 \\
(0.2434)\end{array}$ & $\begin{array}{l}-0.2696 \\
(0.3793)\end{array}$ & $\begin{array}{l}-0.1016 \\
(0.4848)\end{array}$ \\
\hline Urban Population & $\begin{array}{l}-0.0012 \\
(0.0340)\end{array}$ & $\begin{array}{c}0.1446 \\
(0.1107)\end{array}$ & $\begin{array}{c}0.1344 \\
(0.1309)\end{array}$ & $\begin{array}{l}0.2057^{*} \\
(0.1110)\end{array}$ & $\begin{array}{c}0.0661 \\
(0.1292)\end{array}$ & $\begin{array}{c}0.4788^{* *} \\
(0.1896)\end{array}$ \\
\hline Country-Fixed-Effects & YES & YES & YES & YES & YES & YES \\
\hline Time-Fixed-Effects & YES & YES & YES & YES & YES & YES \\
\hline Observations & 1,411 & 1,411 & 1,411 & 1,411 & 1,411 & 1,411 \\
\hline Number of countries & 73 & 73 & 73 & 73 & 73 & 73 \\
\hline$\chi^{2}$ & $\begin{array}{c}38506^{* * *} \\
{[0.00]}\end{array}$ & $\begin{array}{c}1078^{* * *} \\
{[0.00]}\end{array}$ & $\begin{array}{c}1410^{* * *} \\
{[0.00]}\end{array}$ & $\begin{array}{c}10452^{* * *} \\
{[0.00]}\end{array}$ & $\begin{array}{c}3353^{* * *} \\
{[0.00]}\end{array}$ & $\begin{array}{c}825.3^{* * *} \\
{[0.00]}\end{array}$ \\
\hline $\operatorname{AR}(1)$ & $\begin{array}{c}-4.678^{* * *} \\
{[0.00]}\end{array}$ & $\begin{array}{c}-3.456^{* * *} \\
{[0.00]}\end{array}$ & $\begin{array}{c}-2.616^{* * *} \\
{[0.00]}\end{array}$ & $\begin{array}{c}-3.501^{* * *} \\
{[0.00]}\end{array}$ & $\begin{array}{c}-2.740^{* * *} \\
{[0.00]}\end{array}$ & $\begin{array}{c}-1.506^{* * *} \\
{[0.00]}\end{array}$ \\
\hline $\operatorname{AR}(2)$ & $\begin{array}{l}1.247 \\
{[0.21]}\end{array}$ & $\begin{array}{l}0.397 \\
{[0.69]}\end{array}$ & $\begin{array}{l}0.989 \\
{[0.32]}\end{array}$ & $\begin{array}{l}0.776 \\
{[0.44]} \\
\end{array}$ & $\begin{array}{l}0.752 \\
{[0.45]}\end{array}$ & $\begin{array}{c}0.0439 \\
{[0.96]} \\
\end{array}$ \\
\hline
\end{tabular}

Note: See notes of Table A.5. 
Table 2: $N$-shaped Suicidal Kuznets Curve? Female population

\begin{tabular}{lcccccc}
\hline \hline & $(1)$ & $(2)$ & $(3)$ & $(4)$ & $(5)$ & $(6)$ \\
& all & $15-24$ & $25-34$ & $35-54$ & $55-74$ & $75+$ \\
\hline Lagged Dep. Var. & $0.8241^{* * *}$ & $0.4978^{* * *}$ & $0.2437^{* *}$ & $0.6066^{* * *}$ & $0.5719^{* * *}$ & $0.6030^{* * *}$ \\
& $(0.0427)$ & $(0.0421)$ & $(0.0980)$ & $(0.0554)$ & $(0.0875)$ & $(0.0820)$ \\
Per Capita Income & 23.8123 & 39.0247 & -1.7890 & 58.9856 & $120.0029^{* *}$ & -111.9262 \\
& $(16.8466)$ & $(38.4215)$ & $(66.1227)$ & $(39.8600)$ & $(60.2928)$ & $(136.4606)$ \\
Per Capita Income ${ }^{2}$ & -2.4911 & -4.2019 & 0.5390 & -6.0478 & $-12.8491^{* *}$ & 12.0443 \\
& $(1.7562)$ & $(4.1969)$ & $(7.0366)$ & $(4.2406)$ & $(6.4391)$ & $(14.6911)$ \\
Per Capita Income & 0.0871 & 0.1508 & -0.0344 & 0.2041 & $0.4514^{* *}$ & -0.4337 \\
& $(0.0607)$ & $(0.1513)$ & $(0.2474)$ & $(0.1499)$ & $(0.2273)$ & $(0.5265)$ \\
Growth & $-1.6838^{*}$ & $-3.1782^{* * *}$ & -0.5218 & $-1.7867^{*}$ & -2.1579 & -2.4504 \\
& $(0.8838)$ & $(1.1305)$ & $(1.2468)$ & $(1.0380)$ & $(2.3221)$ & $(2.9392)$ \\
Unemployment & 0.0087 & 0.0370 & 0.0134 & 0.0098 & -0.0067 & -0.0247 \\
& $(0.0085)$ & $(0.0357)$ & $(0.0272)$ & $(0.0225)$ & $(0.0259)$ & $(0.0548)$ \\
Fertility & $-0.4405^{* *}$ & -0.7270 & -0.1711 & -0.4285 & $-0.9797^{* *}$ & -1.5068 \\
& $(0.1948)$ & $(0.4687)$ & $(0.4581)$ & $(0.3246)$ & $(0.4110)$ & $(1.1314)$ \\
Life Expectancy & -0.0158 & -0.2085 & 0.0972 & 0.0237 & -0.0459 & 0.0567 \\
& $(0.0360)$ & $(0.1401)$ & $(0.1812)$ & $(0.0676)$ & $(0.0874)$ & $(0.2430)$ \\
Urban Population & 0.0010 & $-0.0520^{* *}$ & 0.0457 & $0.0547^{*}$ & $0.0802^{* *}$ & 0.0490 \\
& $(0.0110)$ & $(0.0255)$ & $(0.0607)$ & $(0.0306)$ & $(0.0382)$ & $(0.0651)$ \\
\hline Country-Fixed-Effects & YES & YES & YES & YES & YES & YES \\
Time-Fixed-Effects & YES & YES & YES & YES & YES & YES \\
Observations & 1,411 & 1,411 & 1,411 & 1,411 & 1,411 & 1,411 \\
Number of countries & 73 & 73 & 73 & 73 & 73 & 73 \\
\hline$\chi^{2}$ & $2920^{* * *}$ & $821.3^{* * *}$ & $367.8^{* * *}$ & $981.3^{* * *}$ & $1423^{* * *}$ & $1027^{* * *}$ \\
AR(1) & {$[0.00]$} & {$[0.00]$} & {$[0.00]$} & {$[0.00]$} & {$[0.00]$} & {$[0.00]$} \\
AR(2) & $-3.755^{* * *}$ & $-2.764^{* * *}$ & $-2.342^{* *}$ & $-2.527^{* *}$ & $-3.243^{* * *}$ & $-3.590^{* * *}$ \\
& {$[0.00]$} & {$[0.00]$} & {$[0.02]$} & {$[0.01]$} & {$[0.00]$} & {$[0.00]$} \\
\hline \hline & $2.128^{* *}$ & 0.847 & 0.386 & 0.398 & 0.311 & 1.287 \\
& {$[0.03]$} & {$[0.40]$} & {$[0.70]$} & {$[0.69]$} & {$[0.76]$} & {$[0.20]$} \\
\hline
\end{tabular}

Note: See notes of Table A.5. 
Table 3: Inflection points of income per capita

\begin{tabular}{|c|c|c|c|c|c|c|}
\hline & \multicolumn{2}{|c|}{ overall } & \multicolumn{3}{|c|}{ male } & female \\
\hline & $25-34$ & $35-54$ & $25-34$ & $35-54$ & $55-74$ & $55-74$ \\
\hline$\hat{\beta}_{1}$ & 151.1112 & 130.5958 & 277.9982 & 246.8616 & 232.6048 & 120.0029 \\
\hline$\hat{\beta}_{2}$ & -15.3520 & -13.8826 & -28.4649 & -26.709 & -24.9591 & -12.8491 \\
\hline$\hat{\beta}_{3}$ & 0.5140 & 0.4894 & 0.9635 & 0.9573 & 0.8743 & 0.4514 \\
\hline $\exp \phi_{1}$ & $\$ 7,304$ & $\$ 6,498$ & $\$ 7,727$ & $\$ 5,266$ & $\$ 3,459$ & $\$ 4,022$ \\
\hline $\exp \phi_{2}$ & $\$ 60,819$ & $\$ 25,129$ & $\$ 46,306$ & $\$ 22,726$ & $\$ 53,260$ & $\$ 43,351$ \\
\hline
\end{tabular}

Note: $\hat{\beta}_{1}, \hat{\beta}_{2}$ and $\hat{\beta}_{3}$ denote the estimated parameters of per capita income, per capita income squared and per capita income cubic, respectively, from Tables A.5, 1, and 2. $\phi_{1}$ and $\phi_{2}$ are calculated based on equations (A.1) and (A.2), respectively. exp is the exponential operator. The inflection points of per capita income, given in the last two rows, are calculated only when each of the $\beta_{1}, \beta_{2}$ and $\beta_{3}$ coefficients are significant at least at the $10 \%$ level of significance in Tables A.5-2. 


\section{A Online Appendix}

\section{A.1 Data description}

The choice of the specific 73 countries (reported in Table A.1) and periods used in this study, is purely driven based on data availability.

\section{[Insert Table A.1 around here]}

A snapshot of the average number of deaths by suicide across genders and age groups is presented in Table A.2 and their evolution depicted in Figure A.1. One can observe that average deaths are consistently higher among the male population compared to the female population across all age groups. In particular, the male to female deaths by suicide ratio ranges between 1.58 and 4.81. Another pattern readily discernable is that suicides of males (females) are the highest in the 35-74 age group, followed by the age groups of 55-74, 25-34 (75+), 15-24 (25-34) and 75+ (15-24). Moreover, suicides have increased to unprecedented levels in 2010, and one could speculate that this might be due to the global financial crisis.

[Insert Table A.2 around here]

[Insert Figure A.1 around here]

Yet, any conclusions reached by observing the patterns of suicides in numbers will be biased due to the changing population patterns overtime that need to be accounted for. Thus, based on the above data, we convert the number of suicides to suicide rates per 100,000 inhabitants (by diving suicides by population and multiplying the resulting number by 100,000), broken down by age and gender in each of the 73 countries. A snapshot of the average suicide rates across genders and age groups presented in Table A.2 and their evolution presented in Figure A.2 reveals age, time and gender heterogeneity. In particular, male suicide rates are consistently higher than female ones. In addition, overall, male and female suicide rates increase with age, which is in line with the theoretical predictions of Hamermesh and Soss (1974). Moreover, overall, male and female suicide rates peak around the mid-1990s and then follow a slight decreasing trend until the end of 
the sample. These features indicate the necessity to take into account the gender-, ageand time- heterogeneity, as well as controlling for country-specific effects in the empirical analysis of suicide rates.

[Insert Table A.3 around here]

[Insert Figure A.2 around here]

Descriptive statistics of the explanatory variables used in this study, as well as those for suicide rates, are reported in Table A.4.

[Insert Table A.4 around here]

\section{A.2 Overall population results}

According to Table A.5 which report the main results for the overall population, there is evidence of gender-- and age-specificity in the relationship between suicide rates and economic development. We observe that the coefficients of per capita income, including squared and cubic counterparts are positive, negative and positive, respectively, across all ages in Table A.5. Yet, they are only significant for the 25-34 (at the 10\% level) and 35-54 (at the 5\% level) age groups, under columns (3) and (4) of Table A.5, respectively. This is suggestive of the existence of an $N$-shaped Suicidal Kuznets curve in the case of the aforementioned age groups.

\section{A.3 Inflection points}

Having found evidence of an $N$-shaped Suicidal Kuznets curve in the aforementioned age groups and genders, we then calculate the inflection points, i.e. the peak and trough of per capita income associated with the $N$-shaped curve as follows

$$
\phi_{1}=\frac{-\hat{\beta}_{2}-\sqrt{\hat{\beta}_{2}^{2}-3 \hat{\beta}_{1} \hat{\beta}_{3}}}{3 \hat{\beta}_{3}}
$$

and

$$
\phi_{2}=\frac{-\hat{\beta}_{2}+\sqrt{\hat{\beta}_{2}^{2}-3 \hat{\beta}_{1} \hat{\beta}_{3}}}{3 \hat{\beta}_{3}}
$$


where $\hat{\beta}_{i}$, with $i=1,2$ and 3 , correspond to the coefficients of log of per capita income, its square and its cubic counterparts, respectively obtained from model (1).

A graphical representation of an $N$-shaped Suicidal Kuznets curve in the context of suicide mortality is given in Figure A.3 in the Appendix. As discussed, the $N$-shaped curve indicates that suicide mortality first increases with income per capita, but decreases after a certain level. This is how a peak is formed. Along with further increase in income per capita, suicide mortality tends to rise again, which provides a trough in the $N$-shaped Suicidal Kuznets curve.

[Insert Figure A.3 around here]

\section{A.4 Robustness Analysis}

In this section, we perform several robustness checks. First, as the estimation results based on the cubic model (1) in the main text provided evidence of an $N$-shaped Suicidal Kuznets curve only for a subset of age groups across genders in our sample, we restrict model (1) from the main analysis to a quadratic version as follows

$$
S_{i j k t}=\alpha_{0}+\alpha_{1} S_{i j k t-1}+\beta_{1} Y+\beta_{2} Y^{2}+\beta_{3} E_{i t}+\beta_{5} D_{i t}+\gamma_{i}+\delta_{t}+\varepsilon_{i t}
$$

where the variables are defined the same as those in the main analysis, and re-estimate model (A.3) again using the two-step System GMM estimator, in order to examine whether such examination could provide evidence for a (inverse) $U$-shaped Suicidal Kuznets curve. Note that evidence of a (inverse) $U$-shaped Suicidal Kuznets curve is supported when the coefficients $\beta_{1}$ and $\beta_{2}$ from the estimated model (A.3) are significantly negative (positive) and positive (negative), respectively. This is motivated by the fact that in several age groups across genders in our sample no significant $N$-shaped relation was found, and the scatter plots presented in Figures 1-6 in the main text were inconclusive between an $N$-shaped and (inverse) $U$-shaped Suicidal Kuznets curve.

The results of this analysis for the overall, male and female population are presented in Tables A.6, A.7 and A.8, respectively.

[Insert Tables A.6-A.8 around here] 
According to these results, we observe that both the coefficients $\beta_{1}$ and $\beta_{2}$ are significantly positive and negative, respectively, only in the case of the overall population in the 25-34 age group (column (3) in Table A.6) and, more specifically, the male population in the 25-34 age group (column (3) in Table A.7). Yet, in the former case, there is evidence of misspecification in the System-GMM model as there is evidence of autocorrelation of order 2. Moreover, the corresponding results (and misspecification tests) of overall and male population in the 25-34 age group presented in column (3) of Tables 2 and 3 in the main analysis, respectively, provide evidence in favour of an $N$-shaped Suicidal Kuznets Curve over an inverse $U$-shaped one. The results of the remaining socioeconomic variables are much in line with our main findings resulting from model (1) in the main analysis, and in line with the existing litarature on suicide mortality; thus providing additional robustness evidence related to the socioeconomic predictors used in our analysis. For instance, the results in Tables A.6-A.8 again suggest that male suicide rates are highly sensitive to the state of the macroeconomy (i.e. to changes in economic growth and unemployment rates), while female suicide rates are generally insensitive to the state of the macroeconomy; and are also in line with the literature (see e.g. Brainerd, 2001; Antonakakis and Collins, 2014, 2015).

As a second robustness analysis, we examine the robustness of our baseline SystemGMM results based on model (1) given in the main analysis to the fixed effects OLS results and compare the coefficient on the lagged dependent variable under fixed effects (FE) with that under the System-GMM. Since our emphasis on System-GMM is motivated by the downward bias in models that include a lagged dependent variable and exhibit unit effects (Nickell, 1981), the lagged dependent variable coefficient in a correctly specified GMM model should not lie below the lagged dependent variable coefficient in the FE model (Bond, 2002). The results of this analysis, which are not presented but available upon request, reveal that the lagged dependent variable coefficient in the GMM model lies above the lagged dependent variable coefficient in the FE model, thus providing additional robustness to the use of System-GMM and its resulting findings. 


\section{References}

Hamermesh, D. S., Soss, N. M., 1974. An Economic Theory of Suicide. Journal of Political Economy 82 (1), 83-98.

Figure A.1: Average deaths due to suicide, by gender and age group
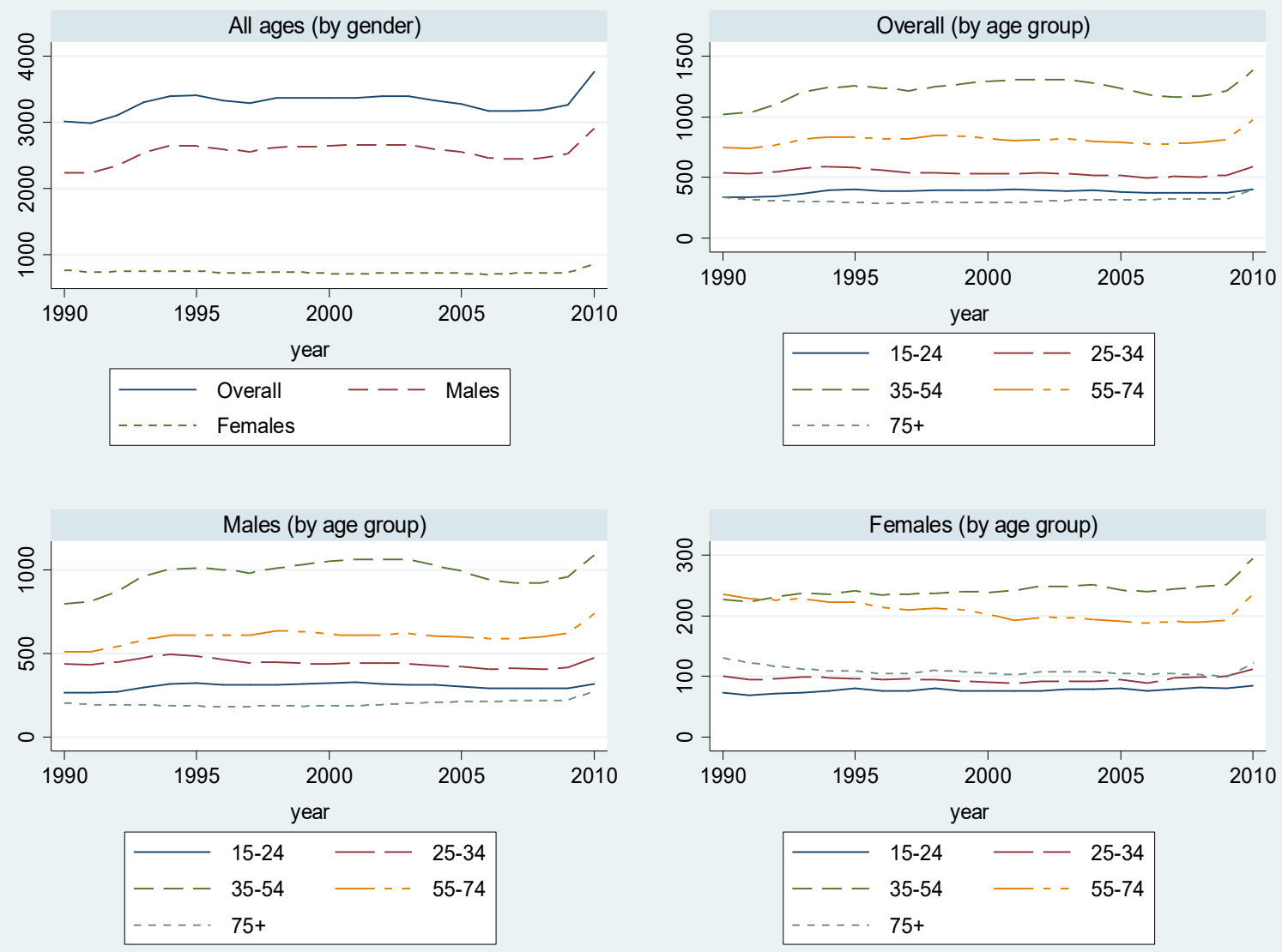

Source: Authors' calculations based on WHO and Official National Statistics databases. 
Figure A.2: Average suicide rates (per 100,000 inhabitants), by gender and age group
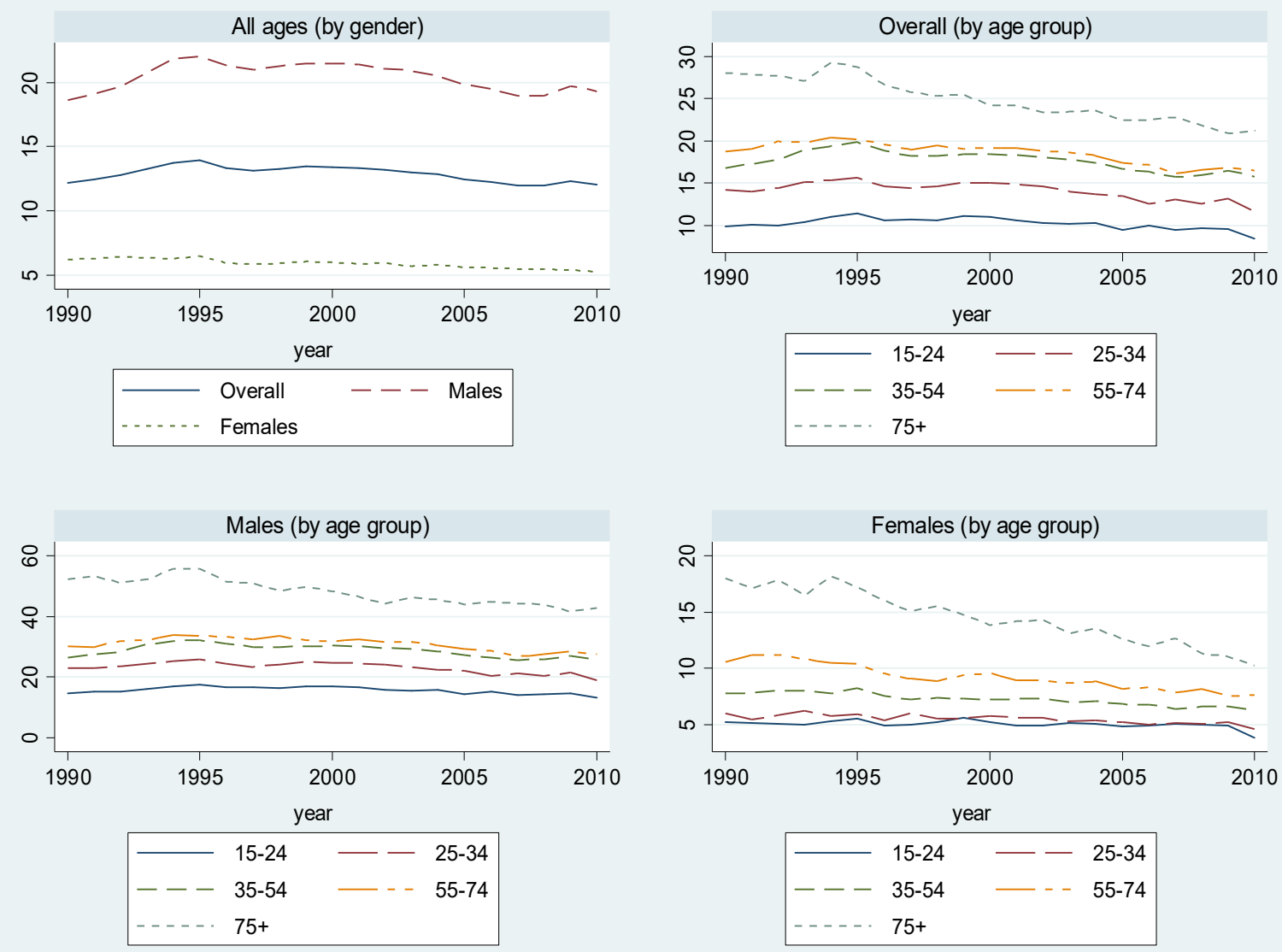

Source: Authors' calculations based on WHO and Official National Statistics databases. 
Figure A.3: Peak and trough of an $N$-shaped Suicidal Kuznets curve

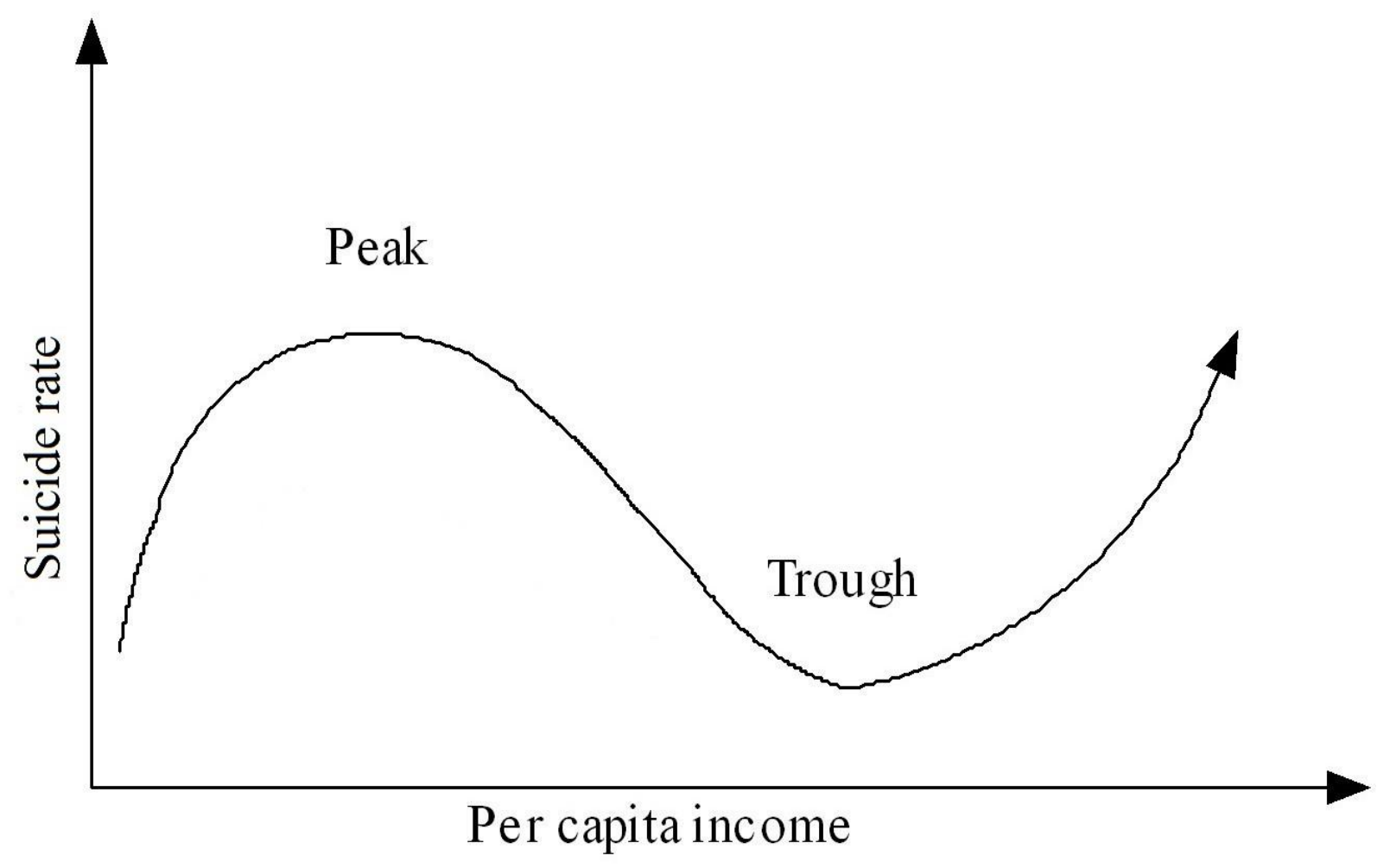

Source: Authors' calculations. 
Table A.1: 73 countries included in the study

\begin{tabular}{llll}
\hline \hline Country & Acronym & Country & Acronym \\
\hline Argentina & ARG & Kuwait & KWT \\
Armenia & ARM & Kyrgyzstan & KGZ \\
Australia & AUS & Latvia & LVA \\
Austria & AUT & Lithuania & LTU \\
Belarus & BLR & Luxembourg & LUX \\
Belgium & BEL & Malta & MLT \\
Belize & BLZ & Mauritius & MUS \\
Brazil & BRA & Mexico & MEX \\
Bulgaria & BLG & Moldova, Republic & MDA \\
Canada & CAN & Netherlands & NED \\
Chile & CHL & New Zealand & NZL \\
Colombia & COL & Nicaragua & NIC \\
Costa Rica & CRI & Norway & NOR \\
Croatia & HRV & Panama & PAN \\
Cuba & CUB & Paraguay & PRY \\
Czech Republic & CZE & Peru & PER \\
Denmark & DNK & Poland & POL \\
Dominican Republic & DOM & Portugal & PRT \\
Ecuador & ECU & Puerto Rico & PRI \\
El Salvador & SLV & Romania & ROM \\
Estonia & EST & Russian Federation & RUS \\
Finland & FIN & Serbia & SRB \\
France & FRA & Singapore & SGP \\
Georgia & GEO & Slovakia & SVK \\
Germany & DEU & Slovenia & SVN \\
Greece & GRC & South Africa & ZAF \\
Guatemala & GTM & Spain & ESP \\
Guyana & GUY & Suriname & SUR \\
Hong Kong SAR, China & HKG & Sweden & SWE \\
Hungary & HUN & Switzerland & CHE \\
Iceland & ISL & TFYR Macedonia & MKD \\
Ireland & IRE & Ukraine & UKR \\
Israel & ISR & United Kingdom & UK \\
Italy & United States & US \\
Japan & URuay & URY \\
Kazakhstan & VEN \\
Korea, Republic & & \\
\hline \hline & KO & \\
\hline
\end{tabular}


Table A.2: Snapshot of average deaths by suicide, by age, gender and selected years in the 73 countries

\begin{tabular}{llllll}
\hline \hline & & Overall & Male & Female & Male/female ratio \\
\hline 1990 & All ages & 3008 & 2234 & 774 & 2.89 \\
$15-24$ & 341 & 267 & 74 & 3.61 \\
& $25-34$ & 537 & 437 & 100 & 4.37 \\
$35-54$ & 1022 & 795 & 227 & 3.50 \\
& $55-74$ & 745 & 509 & 236 & 2.16 \\
& $75+$ & 336 & 206 & 130 & 1.58 \\
& All ages & 3401 & 2642 & 759 & 3.48 \\
1595 & $15-24$ & 401 & 321 & 80 & 4.01 \\
& $25-34$ & 582 & 485 & 97 & 5.00 \\
& $35-54$ & 1252 & 1011 & 241 & 4.20 \\
5000 & $55-74$ & 832 & 610 & 222 & 2.75 \\
& $75+$ & 296 & 186 & 110 & 1.69 \\
& All ages & 3365 & 2643 & 722 & 3.66 \\
$15-24$ & 397 & 321 & 76 & 4.22 \\
& $25-34$ & 529 & 438 & 91 & 4.81 \\
& $35-54$ & 1290 & 1051 & 239 & 4.40 \\
$55-74$ & 818 & 615 & 203 & 3.03 \\
& $75+$ & 293 & 188 & 105 & 1.79 \\
All ages & 3274 & 2550 & 724 & 3.52 \\
$15-24$ & 382 & 301 & 81 & 3.72 \\
& $25-34$ & 515 & 420 & 95 & 4.42 \\
& $35-54$ & 1233 & 991 & 242 & 4.06 \\
$55-74$ & 792 & 601 & 191 & 3.15 \\
& $75+$ & 318 & 213 & 105 & 2.03 \\
All ages & 3767 & 2909 & 858 & 3.39 \\
$15-24$ & 401 & 316 & 85 & 3.72 \\
& $25-34$ & 585 & 473 & 112 & 4.22 \\
$35-54$ & 1381 & 1087 & 294 & 3.70 \\
$55-74$ & 975 & 739 & 236 & 3.13 \\
& $75+$ & 395 & 273 & 122 & 2.24 \\
& All ages & 3296 & 2554 & 742 & 3.44 \\
$15-24$ & 381 & 304 & 77 & 3.95 \\
$25-34$ & 538 & 442 & 96 & 4.60 \\
$35-54$ & 1222 & 980 & 242 & 4.05 \\
$55-74$ & 810 & 602 & 208 & 2.89 \\
& $75+$ & 311 & 202 & 109 & 1.85 \\
\hline \hline
\end{tabular}

Note: Authors' calculations based on WHO and Official National Statistics databases. 
Table A.3: Snapshot of average suicide rates, by age, gender and selected years in the 73 countries

\begin{tabular}{|c|c|c|c|c|c|}
\hline & & Overall & Male & Female & Male/female ratio \\
\hline \multirow[t]{6}{*}{1990} & All ages & 12.20 & 18.65 & 6.23 & 2.99 \\
\hline & $15-24$ & 9.85 & 14.78 & 5.26 & 2.81 \\
\hline & $25-34$ & 14.27 & 23.04 & 6.01 & 3.83 \\
\hline & $35-54$ & 16.76 & 26.46 & 7.81 & 3.39 \\
\hline & $55-74$ & 18.73 & 30.11 & 10.56 & 2.85 \\
\hline & $75+$ & 28.08 & 52.18 & 18.02 & 2.90 \\
\hline \multirow[t]{6}{*}{1995} & All ages & 13.95 & 22.04 & 6.48 & 3.40 \\
\hline & $15-24$ & 11.41 & 17.56 & 5.57 & 3.15 \\
\hline & $25-34$ & 15.63 & 25.75 & 5.98 & 4.31 \\
\hline & $35-54$ & 19.86 & 32.26 & 8.27 & 3.90 \\
\hline & $55-74$ & 20.21 & 33.60 & 10.39 & 3.23 \\
\hline & $75+$ & 28.80 & 55.80 & 17.21 & 3.24 \\
\hline \multirow[t]{6}{*}{2000} & All ages & 13.44 & 21.48 & 5.98 & 3.59 \\
\hline & $15-24$ & 10.98 & 17.03 & 5.21 & 3.27 \\
\hline & $25-34$ & 15.07 & 24.85 & 5.80 & 4.28 \\
\hline & $35-54$ & 18.41 & 30.33 & 7.26 & 4.18 \\
\hline & $55-74$ & 19.16 & 31.91 & 9.58 & 3.33 \\
\hline & $75+$ & 24.27 & 48.37 & 13.84 & 3.49 \\
\hline \multirow[t]{6}{*}{2005} & All ages & 12.46 & 19.87 & 5.58 & 3.56 \\
\hline & $15-24$ & 9.53 & 14.49 & 4.85 & 2.99 \\
\hline & $25-34$ & 13.50 & 22.25 & 5.21 & 4.27 \\
\hline & $35-54$ & 16.70 & 27.24 & 6.83 & 3.99 \\
\hline & $55-74$ & 17.41 & 29.30 & 8.22 & 3.56 \\
\hline & $75+$ & 22.46 & 44.04 & 12.64 & 3.48 \\
\hline \multirow[t]{6}{*}{2010} & All ages & 12.04 & 19.35 & 5.25 & 3.69 \\
\hline & $15-24$ & 8.44 & 13.21 & 3.84 & 3.44 \\
\hline & $25-34$ & 11.64 & 18.86 & 4.65 & 4.06 \\
\hline & $35-54$ & 15.82 & 25.76 & 6.33 & 4.07 \\
\hline & $55-74$ & 16.53 & 27.55 & 7.65 & 3.60 \\
\hline & $75+$ & 21.26 & 42.67 & 10.26 & 4.16 \\
\hline \multirow[t]{6}{*}{ 1990-2010 average } & All ages & 12.89 & 20.45 & 5.88 & 3.48 \\
\hline & $10-24$ & 10.25 & 15.73 & 5.06 & 3.11 \\
\hline & $25-34$ & 14.13 & 23.21 & 5.52 & 4.20 \\
\hline & $35-54$ & 17.68 & 28.82 & 7.28 & 3.96 \\
\hline & $55-74$ & 18.58 & 30.98 & 9.24 & 3.35 \\
\hline & $75+$ & 24.88 & 48.21 & 14.52 & 3.32 \\
\hline
\end{tabular}


Table A.4: Descriptive statistics and sources

\begin{tabular}{|c|c|c|c|c|c|c|}
\hline Variable & Obs & Mean & Std. Dev. & Min & Max & Source \\
\hline \multicolumn{6}{|c|}{ Male Suicide rate (per 100,000 inhabitants) } & World Health Organisation, \\
\hline All ages & 1490 & 20.45 & 15.46 & 0.41 & 83.58 & Mortality Database \& \\
\hline $15-24$ & 1490 & 15.73 & 11.06 & 0.49 & 65.52 & Official National Statistics \\
\hline $25-34$ & 1490 & 23.21 & 17.52 & 0.63 & 93.36 & \\
\hline $35-54$ & 1490 & 28.82 & 24.26 & 0.42 & 151.45 & \\
\hline $55-74$ & 1490 & 30.98 & 23.65 & 0.78 & 124.78 & \\
\hline $75+$ & 1490 & 48.21 & 34.39 & 0.74 & 191.00 & \\
\hline \multicolumn{7}{|c|}{ Female Suicide rate (per 100,000 inhabitants) } \\
\hline All ages & 1490 & 5.89 & 4.03 & 0.11 & 25.17 & \\
\hline $15-24$ & 1490 & 5.06 & 4.06 & 0.12 & 33.36 & \\
\hline $25-34$ & 1490 & 5.52 & 3.82 & 0.06 & 30.33 & \\
\hline $35-54$ & 1490 & 7.28 & 5.05 & 0.17 & 26.85 & \\
\hline $55-74$ & 1490 & 9.24 & 6.83 & 0.17 & 37.90 & \\
\hline $75+$ & 1490 & 14.52 & 13.34 & 0.28 & 104.38 & \\
\hline \multicolumn{7}{|c|}{ Overall Suicide rate (per 100,000 inhabitants) } \\
\hline All ages & 1490 & 12.88 & 9.11 & 0.26 & 47.87 & \\
\hline $15-24$ & 1490 & 10.25 & 6.86 & 0.33 & 39.52 & \\
\hline $25-34$ & 1490 & 14.13 & 10.03 & 0.38 & 52.54 & \\
\hline $35-54$ & 1490 & 17.68 & 13.82 & 0.33 & 85.94 & \\
\hline $55-74$ & 1490 & 18.81 & 13.36 & 0.48 & 71.64 & \\
\hline $75+$ & 1490 & 25.52 & 19.38 & 0.32 & 122.30 & \\
\hline GDP per capita, PPP & 1529 & 21492.73 & 16717.24 & 1696.364 & 96711.05 & World Development Indicators \\
\hline \multicolumn{7}{|c|}{ (constant 2011 international US\$) } \\
\hline & 1,457 & 0.02 & 0.06 & -0.60 & 0.66 & World Development Indicators \\
\hline \multicolumn{6}{|l|}{ Unemployment rate } & World Development Indicators \\
\hline male & 1460 & 8.53 & 5.48 & 0.70 & 37.00 & \\
\hline female & 1460 & 10.36 & 7.07 & 0.60 & 40.10 & \\
\hline total & 1460 & 9.22 & 5.86 & 0.70 & 37.30 & \\
\hline Fertility rate & 1525 & 2.02 & 0.75 & 0.90 & 5.58 & World Development Indicators \\
\hline Share of urban population & 1533 & 70.23 & 15.82 & 28.31 & 100 & World Development Indicators \\
\hline \multicolumn{6}{|l|}{ Life expectancy } & World Development Indicators \\
\hline male & 1525 & 70.75 & 5.46 & 50.31 & 87.70 & \\
\hline female & 1525 & 77.38 & 4.57 & 52.87 & 86.44 & \\
\hline total & 1525 & 73.98 & 4.93 & 51.56 & 85.16 & \\
\hline
\end{tabular}


Table A.5: $N$-shaped Suicidal Kuznets Curve? Overall population

\begin{tabular}{|c|c|c|c|c|c|c|}
\hline & (1) & (2) & (3) & (4) & (5) & (6) \\
\hline & all & $15-24$ & $25-34$ & $35-54$ & $55-74$ & $75+$ \\
\hline Lagged Dep. Var. & $\begin{array}{c}1.0101^{* * *} \\
(0.0373)\end{array}$ & $\begin{array}{c}0.5281^{* * *} \\
(0.0519)\end{array}$ & $\begin{array}{c}0.4710^{* * *} \\
(0.1497)\end{array}$ & $\begin{array}{c}0.9168^{* * *} \\
(0.0393)\end{array}$ & $\begin{array}{c}0.7419^{* * *} \\
(0.0744)\end{array}$ & $\begin{array}{c}0.7103^{* * *} \\
(0.0706)\end{array}$ \\
\hline Per Capita Income & $\begin{array}{c}34.3655 \\
(22.7372)\end{array}$ & $\begin{array}{c}42.5826 \\
(45.9863)\end{array}$ & $\begin{array}{c}151.1112^{*} \\
(78.8301)\end{array}$ & $\begin{array}{c}130.5958^{* *} \\
(60.8059)\end{array}$ & $\begin{array}{c}88.1711 \\
(93.5752)\end{array}$ & $\begin{array}{c}-95.5058 \\
(107.1579)\end{array}$ \\
\hline Per Capita Income ${ }^{2}$ & $\begin{array}{l}-3.7794 \\
(2.4606)\end{array}$ & $\begin{array}{l}-4.1847 \\
(4.9392)\end{array}$ & $\begin{array}{c}-15.3520^{*} \\
(8.3625)\end{array}$ & $\begin{array}{c}-13.8826^{* *} \\
(6.4484)\end{array}$ & $\begin{array}{l}-9.4940 \\
(9.9353)\end{array}$ & $\begin{array}{c}10.6911 \\
(11.6444)\end{array}$ \\
\hline Per Capita Income ${ }^{3}$ & $\begin{array}{c}0.1386 \\
(0.0878)\end{array}$ & $\begin{array}{c}0.1385 \\
(0.1762)\end{array}$ & $\begin{array}{l}0.5140^{*} \\
(0.2935)\end{array}$ & $\begin{array}{c}0.4894^{* *} \\
(0.2257)\end{array}$ & $\begin{array}{c}0.3338 \\
(0.3499)\end{array}$ & $\begin{array}{l}-0.3858 \\
(0.4186)\end{array}$ \\
\hline Growth & $\begin{array}{c}-4.4165^{* *} \\
(1.7507)\end{array}$ & $\begin{array}{c}-3.2462^{* *} \\
(1.3489)\end{array}$ & $\begin{array}{l}-3.5182 \\
(2.7664)\end{array}$ & $\begin{array}{c}-7.8354^{*} \\
(4.3902)\end{array}$ & $\begin{array}{c}-10.7238^{* *} \\
(5.1199)\end{array}$ & $\begin{array}{l}-5.2495 \\
(3.6116)\end{array}$ \\
\hline Unemployment & $\begin{array}{c}0.0094 \\
(0.0192)\end{array}$ & $\begin{array}{c}0.0757 \\
(0.0536)\end{array}$ & $\begin{array}{c}0.0994 \\
(0.0690)\end{array}$ & $\begin{array}{c}0.0231 \\
(0.0496)\end{array}$ & $\begin{array}{c}0.0004 \\
(0.0387)\end{array}$ & $\begin{array}{c}0.0353 \\
(0.0735)\end{array}$ \\
\hline Fertility & $\begin{array}{l}-0.3169 \\
(0.2692)\end{array}$ & $\begin{array}{c}-1.5337^{* *} \\
(0.6297)\end{array}$ & $\begin{array}{c}-2.0365^{* *} \\
(0.9262)\end{array}$ & $\begin{array}{l}-0.7322 \\
(0.4762)\end{array}$ & $\begin{array}{c}-1.8195^{* *} \\
(0.8345)\end{array}$ & $\begin{array}{l}-1.7447 \\
(1.3091)\end{array}$ \\
\hline Life Expectancy & $\begin{array}{c}-0.0553 \\
(0.0840)\end{array}$ & $\begin{array}{c}-0.2789^{* *} \\
(0.1215)\end{array}$ & $\begin{array}{c}-0.6485^{* *} \\
(0.2726)\end{array}$ & $\begin{array}{l}-0.2195 \\
(0.1593)\end{array}$ & $\begin{array}{c}-0.1770 \\
(0.2039)\end{array}$ & $\begin{array}{c}0.1069 \\
(0.1439)\end{array}$ \\
\hline Urban Population & $\begin{array}{c}0.0054 \\
(0.0179)\end{array}$ & $\begin{array}{c}0.0210 \\
(0.0512)\end{array}$ & $\begin{array}{c}0.0792 \\
(0.0854)\end{array}$ & $\begin{array}{c}0.1340^{* *} \\
(0.0594)\end{array}$ & $\begin{array}{c}0.0543 \\
(0.0825)\end{array}$ & $\begin{array}{c}0.1637^{*} \\
(0.0973)\end{array}$ \\
\hline Country-Fixed-Effects & YES & YES & YES & YES & YES & YES \\
\hline Time-Fixed-Effects & YES & YES & YES & YES & YES & YES \\
\hline Observations & 1,411 & 1,411 & 1,411 & 1,411 & 1,411 & 1,411 \\
\hline Number of countries & 73 & 73 & 73 & 73 & 73 & 73 \\
\hline$\chi^{2}$ & $\begin{array}{c}22250^{* * *} \\
{[0.00]}\end{array}$ & $\begin{array}{c}1416^{* * *} \\
{[0.00]}\end{array}$ & $\begin{array}{c}834.4^{* * *} \\
{[0.00]}\end{array}$ & $\begin{array}{c}12131^{* * *} \\
{[0.00]}\end{array}$ & $\begin{array}{c}3099^{* * *} \\
{[0.00]}\end{array}$ & $\begin{array}{c}1573^{* * *} \\
{[0.00]}\end{array}$ \\
\hline $\operatorname{AR}(1)$ & $\begin{array}{c}-4.183^{* * *} \\
{[0.00]}\end{array}$ & $\begin{array}{c}-3.470^{* * *} \\
{[0.00]}\end{array}$ & $\begin{array}{c}-2.518^{* *} \\
{[0.01]}\end{array}$ & $\begin{array}{c}-2.943^{* * *} * \\
{[0.00]}\end{array}$ & $\begin{array}{c}-3.073^{* * *} \\
{[0.00]}\end{array}$ & $\begin{array}{c}-4.025^{* * *} \\
{[0.00]}\end{array}$ \\
\hline $\operatorname{AR}(2)$ & $\begin{array}{l}1.951^{*} \\
{[0.05]}\end{array}$ & $\begin{array}{l}0.451 \\
{[0.65]}\end{array}$ & $\begin{array}{l}0.597 \\
{[0.55]}\end{array}$ & $\begin{array}{l}0.411 \\
{[0.68]}\end{array}$ & $\begin{array}{l}0.621 \\
{[0.53]}\end{array}$ & $\begin{array}{l}0.325 \\
{[0.74]}\end{array}$ \\
\hline
\end{tabular}

Note: Heteroskedasticity and autocorrelation robust standard errors in parentheses; $p$-values in brackets. Instruments are restricted to 2 lags to minimize instrument count. Endogenous variable is the lagged dependent variable. First order serial correlation in first-differenced residuals (AR(1) significant) with no second order serial correlation $(\operatorname{AR}(2)$ insignificant) supports the claim that instruments for the SystemGMM models are valid. *, ${ }^{* *}$ and ${ }^{* * *}$ indicate significance at $10 \%, 5 \%$ and $1 \%$ level, respectively. 
Table A.6: $U$-shaped Suicidal Kuznets Curve? Overall population

\begin{tabular}{|c|c|c|c|c|c|c|}
\hline & (1) & $(2)$ & $(3)$ & $(4)$ & $(5)$ & $(6)$ \\
\hline & all & $15-24$ & $25-34$ & $35-54$ & $55-74$ & $75+$ \\
\hline Lagged Dep. Var. & $\begin{array}{c}0.9392^{* * *} \\
(0.0431)\end{array}$ & $\begin{array}{c}0.5212^{* * *} \\
(0.0567)\end{array}$ & $\begin{array}{c}0.4898^{* * *} \\
(0.1488)\end{array}$ & $\begin{array}{c}0.9294^{* * *} \\
(0.0386)\end{array}$ & $\begin{array}{c}0.7452^{* * * *} \\
(0.0792)\end{array}$ & $\begin{array}{c}0.7065^{* * *} \\
(0.0703)\end{array}$ \\
\hline Per Capita Income & $\begin{array}{l}-1.9167 \\
(2.2131)\end{array}$ & $\begin{array}{c}8.6512 \\
(5.3307)\end{array}$ & $\begin{array}{l}13.5118^{*} \\
(7.9118)\end{array}$ & $\begin{array}{c}1.6834 \\
(6.8773)\end{array}$ & $\begin{array}{c}-2.3475 \\
(14.9815)\end{array}$ & $\begin{array}{c}5.3555 \\
(10.7046)\end{array}$ \\
\hline Per Capita Income ${ }^{2}$ & $\begin{array}{c}0.1144 \\
(0.1222)\end{array}$ & $\begin{array}{l}-0.4206 \\
(0.2898)\end{array}$ & $\begin{array}{c}-0.7258^{*} \\
(0.4314)\end{array}$ & $\begin{array}{l}-0.0670 \\
(0.3822)\end{array}$ & $\begin{array}{c}0.0675 \\
(0.8043)\end{array}$ & $\begin{array}{c}-0.1584 \\
(0.6280)\end{array}$ \\
\hline Growth & $\begin{array}{c}-4.6423^{* *} \\
(1.8702)\end{array}$ & $\begin{array}{c}-3.6482^{* * * *} \\
(1.3550)\end{array}$ & $\begin{array}{l}-3.8703 \\
(2.6595)\end{array}$ & $\begin{array}{c}-8.1100^{*} \\
(4.4809)\end{array}$ & $\begin{array}{c}-11.7009^{* *} \\
(5.1582)\end{array}$ & $\begin{array}{l}-4.9881 \\
(3.5141)\end{array}$ \\
\hline Unemployment & $\begin{array}{c}0.0096 \\
(0.0196)\end{array}$ & $\begin{array}{c}0.0823 \\
(0.0557)\end{array}$ & $\begin{array}{l}0.1124^{*} \\
(0.0660)\end{array}$ & $\begin{array}{c}0.0278 \\
(0.0528)\end{array}$ & $\begin{array}{c}0.0027 \\
(0.0394)\end{array}$ & $\begin{array}{c}0.0223 \\
(0.0748)\end{array}$ \\
\hline Fertility & $\begin{array}{l}-0.2811 \\
(0.2778)\end{array}$ & $\begin{array}{c}-1.5383^{* *} \\
(0.6539)\end{array}$ & $\begin{array}{r}-1.8514^{*} \\
(0.9567)\end{array}$ & $\begin{array}{l}-0.4775 \\
(0.4415)\end{array}$ & $\begin{array}{c}-1.7210^{* *} \\
(0.8491)\end{array}$ & $\begin{array}{l}-1.8221 \\
(1.2608)\end{array}$ \\
\hline Life Expectancy & $\begin{array}{c}-0.0416 \\
(0.0904)\end{array}$ & $\begin{array}{c}-0.3059^{* *} \\
(0.1280)\end{array}$ & $\begin{array}{c}-0.6347^{* *} \\
(0.2609)\end{array}$ & $\begin{array}{l}-0.1998 \\
(0.1585)\end{array}$ & $\begin{array}{l}-0.1775 \\
(0.2063)\end{array}$ & $\begin{array}{c}0.0971 \\
(0.1405)\end{array}$ \\
\hline Urban Population & $\begin{array}{c}0.0031 \\
(0.0183)\end{array}$ & $\begin{array}{c}0.0255 \\
(0.0504)\end{array}$ & $\begin{array}{c}0.0675 \\
(0.0744)\end{array}$ & $\begin{array}{c}0.1187^{* *} \\
(0.0533)\end{array}$ & $\begin{array}{c}0.0522 \\
(0.0827)\end{array}$ & $\begin{array}{l}0.1782^{*} \\
(0.0996)\end{array}$ \\
\hline Country-Fixed-Effects & YES & YES & YES & YES & YES & YES \\
\hline Time-Fixed-Effects & YES & YES & YES & YES & YES & YES \\
\hline Observations & 1,411 & 1,411 & 1,411 & 1,411 & 1,411 & 1,411 \\
\hline Number of country_id & 73 & 73 & 73 & 73 & 73 & 73 \\
\hline$\chi^{2}$ & $\begin{array}{c}28450^{* * *} \\
{[0.00]}\end{array}$ & $\begin{array}{c}1189^{* * *} \\
{[0.00]}\end{array}$ & $\begin{array}{c}910.2^{* * *} \\
{[0.00]}\end{array}$ & $\begin{array}{c}14422^{* * *} \\
{[0.00]}\end{array}$ & $\begin{array}{c}2392^{* * *} \\
{[0.00]}\end{array}$ & $\begin{array}{c}1469^{* * *} \\
{[0.00]}\end{array}$ \\
\hline $\operatorname{AR}(1)$ & $\begin{array}{c}-4.188^{* * *} \\
{[0.00]}\end{array}$ & $\begin{array}{c}-3.440^{* * *} \\
{[0.00]}\end{array}$ & $\begin{array}{c}-2.846^{* * *} \\
{[0.00]}\end{array}$ & $\begin{array}{c}-3.895^{* * *} \\
{[0.00]}\end{array}$ & $\begin{array}{c}-3.189^{* * *} \\
{[0.00]}\end{array}$ & $\begin{array}{c}-4.520^{* * *} \\
{[0.00]}\end{array}$ \\
\hline $\operatorname{AR}(2)$ & $\begin{array}{c}1.964^{* *} \\
{[0.05]}\end{array}$ & $\begin{array}{l}0.592 \\
{[0.55]}\end{array}$ & $\begin{array}{c}1.789^{*} \\
{[0.07]}\end{array}$ & $\begin{array}{l}1.413 \\
{[0.16]}\end{array}$ & $\begin{array}{l}1.552 \\
{[0.12]}\end{array}$ & $\begin{array}{l}0.552 \\
{[0.58]}\end{array}$ \\
\hline
\end{tabular}

Note: Heteroskedasticity and autocorrelation robust standard errors in parentheses; $p$-values in brackets. Instruments are restricted to 2 lags to minimize instrument count. Endogenous variable is the lagged dependent variable. First order serial correlation in first-differenced residuals (AR(1) significant) with no second order serial correlation $(\operatorname{AR}(2)$ insignificant) supports the claim that instruments for the SystemGMM models are valid. *,** and ${ }^{* * *}$ indicate significance at $10 \%, 5 \%$ and $1 \%$ level, respectively. 
Table A.7: $U$-shaped Suicidal Kuznets Curve? Male population

\begin{tabular}{|c|c|c|c|c|c|c|}
\hline & $(1)$ & $(2)$ & $(3)$ & $(4)$ & $(5)$ & (6) \\
\hline & all & $15-24$ & $25-34$ & $35-54$ & $55-74$ & $75+$ \\
\hline \multirow[t]{2}{*}{ Lagged Dep. Var. } & $0.9929 * * *$ & $0.4523^{* * *}$ & $0.4802^{* * *}$ & $0.9235^{* * *}$ & $0.7339^{* * *}$ & $0.4754^{* * *}$ \\
\hline & $(0.0365)$ & $(0.0797)$ & $(0.1262)$ & $(0.0403)$ & $(0.0939)$ & $(0.0938)$ \\
\hline \multirow[t]{2}{*}{ Per Capita Income } & -4.8041 & 13.0133 & $26.1023^{*}$ & -6.8187 & -2.8473 & $39.9132^{*}$ \\
\hline & $(4.3920)$ & $(8.5785)$ & $(14.4900)$ & (12.3257) & $(18.4420)$ & $(23.9427)$ \\
\hline \multirow[t]{2}{*}{ Per Capita Income ${ }^{2}$} & 0.2673 & -0.6163 & $-1.3981^{*}$ & 0.3819 & 0.0115 & -1.9337 \\
\hline & $(0.2384)$ & $(0.4690)$ & $(0.7875)$ & $(0.6799)$ & $(1.0001)$ & $(1.4616)$ \\
\hline \multirow[t]{2}{*}{ Growth } & $-8.0539 * *$ & -2.5804 & $-8.5781^{*}$ & $-16.8803^{* *}$ & $-15.1422^{* *}$ & -6.8732 \\
\hline & $(3.3205)$ & $(1.7280)$ & $(4.9978)$ & $(7.7110)$ & $(6.9605)$ & $(7.0812)$ \\
\hline \multirow[t]{2}{*}{ Unemployment } & 0.0308 & $0.1372^{* *}$ & $0.2070^{* *}$ & 0.0133 & 0.0724 & 0.0367 \\
\hline & $(0.0399)$ & $(0.0646)$ & $(0.0954)$ & $(0.0848)$ & $(0.0854)$ & $(0.1479)$ \\
\hline \multirow[t]{2}{*}{ Fertility } & $-0.8214^{* *}$ & $-2.9150 * * *$ & $-2.6058^{*}$ & $-1.3625^{* *}$ & $-2.5988^{*}$ & -3.1278 \\
\hline & $(0.4052)$ & $(0.8681)$ & $(1.4093)$ & $(0.6680)$ & $(1.3659)$ & $(3.1044)$ \\
\hline \multirow[t]{2}{*}{ Life Expectancy } & -0.1049 & $-0.5392^{* * *}$ & $-1.0787 * * *$ & -0.3011 & -0.2894 & -0.1426 \\
\hline & $(0.1284)$ & $(0.1735)$ & $(0.3628)$ & $(0.2358)$ & $(0.3772)$ & $(0.4860)$ \\
\hline \multirow[t]{2}{*}{ Urban Population } & -0.0116 & 0.1436 & 0.1304 & $0.1888^{*}$ & 0.0543 & $0.4995^{* * *}$ \\
\hline & $(0.0381)$ & $(0.1093)$ & $(0.1122)$ & $(0.0973)$ & $(0.1384)$ & $(0.1774)$ \\
\hline Country-Fixed-Effects & YES & YES & YES & YES & YES & YES \\
\hline Time-Fixed-Effects & YES & YES & YES & YES & YES & YES \\
\hline Observations & 1,411 & 1,411 & 1,411 & 1,411 & 1,411 & 1,411 \\
\hline Number of countries & 73 & 73 & 73 & 73 & 73 & 73 \\
\hline \multirow[t]{2}{*}{$\chi^{2}$} & $41219^{* * *}$ & $979.5^{* * *}$ & $1447^{* * *}$ & $11816^{* * *}$ & $2538^{* * *}$ & $760.7^{* * *}$ \\
\hline & {$[0.00]$} & {$[0.00]$} & {$[0.00]$} & {$[0.00]$} & {$[0.00]$} & {$[0.00]$} \\
\hline \multirow[t]{2}{*}{$\operatorname{AR}(1)$} & $-4.667 * * *$ & $-3.432^{* * *}$ & $-2.787 * * *$ & $-3.984^{* * *}$ & $-3.228 * * *$ & $-3.979 * * *$ \\
\hline & {$[0.00]$} & {$[0.00]$} & {$[0.00]$} & {$[0.00]$} & {$[0.00]$} & {$[0.00]$} \\
\hline \multirow[t]{2}{*}{$\operatorname{AR}(2)$} & 1.266 & 0.685 & 1.606 & 1.396 & $1.647^{*}$ & 0.0943 \\
\hline & {$[0.20]$} & {$[0.49]$} & {$[0.11]$} & {$[0.16]$} & {$[0.10]$} & {$[0.92]$} \\
\hline
\end{tabular}

Note: Heteroskedasticity and autocorrelation robust standard errors in parentheses; $p$-values in brackets. Instruments are restricted to 2 lags to minimize instrument count. Endogenous variable is the lagged dependent variable. First order serial correlation in first-differenced residuals (AR(1) significant) with no second order serial correlation (AR(2) insignificant) supports the claim that instruments for the SystemGMM models are valid. * ${ }^{* *}$ and ${ }^{* * *}$ indicate significance at $10 \%, 5 \%$ and $1 \%$ level, respectively. 
Table A.8: $U$-shaped Suicidal Kuznets Curve? Female population

\begin{tabular}{lcccccc}
\hline \hline & $(1)$ & $(2)$ & $(3)$ & $(4)$ & $(5)$ & $(6)$ \\
& all & $15-24$ & $25-34$ & $35-54$ & $55-74$ & $75+$ \\
\hline Lagged Dep. Var. & $0.8303^{* * *}$ & $0.4990^{* * *}$ & $0.2400^{* *}$ & $0.6134^{* * *}$ & $0.5826^{* * *}$ & $0.6009^{* * *}$ \\
& $(0.0429)$ & $(0.0435)$ & $(0.0984)$ & $(0.0583)$ & $(0.0940)$ & $(0.0810)$ \\
Per Capita Income & 0.4517 & -0.3145 & 8.1537 & 4.8661 & 1.1323 & 2.7854 \\
& $(1.5525)$ & $(3.3591)$ & $(5.8838)$ & $(3.6336)$ & $(6.9685)$ & $(15.1322)$ \\
Per Capita Income ${ }^{2}$ & -0.0099 & 0.0349 & -0.4888 & -0.2659 & -0.1050 & -0.2130 \\
& $(0.0827)$ & $(0.1972)$ & $(0.3393)$ & $(0.2085)$ & $(0.3931)$ & $(0.8752)$ \\
Growth & $-1.5718^{*}$ & $-3.2142^{* * *}$ & -0.4705 & $-1.8929^{*}$ & -2.9453 & -2.6901 \\
& $(0.8675)$ & $(1.1767)$ & $(1.3611)$ & $(1.0855)$ & $(2.5839)$ & $(2.9683)$ \\
Unemployment & 0.0111 & 0.0403 & 0.0145 & 0.0183 & 0.0096 & -0.0296 \\
& $(0.0078)$ & $(0.0345)$ & $(0.0248)$ & $(0.0226)$ & $(0.0242)$ & $(0.0539)$ \\
Fertility & $-0.3980^{* *}$ & -0.7005 & -0.1063 & -0.3784 & $-0.8713^{* *}$ & -1.6486 \\
& $(0.1860)$ & $(0.4638)$ & $(0.4325)$ & $(0.2901)$ & $(0.4258)$ & $(1.0957)$ \\
Life Expectancy & -0.0120 & -0.1940 & 0.1097 & 0.0323 & 0.0006 & 0.0502 \\
& $(0.0332)$ & $(0.1398)$ & $(0.1822)$ & $(0.0580)$ & $(0.0843)$ & $(0.2352)$ \\
Urban Population & 0.0003 & $-0.0563^{* *}$ & 0.0517 & $0.0515^{*}$ & $0.0717^{*}$ & 0.0552 \\
& $(0.0109)$ & $(0.0262)$ & $(0.0581)$ & $(0.0284)$ & $(0.0379)$ & $(0.0658)$ \\
\hline Country-Fixed-Effects & YES & YES & YES & YES & YES & YES \\
Time-Fixed-Effects & YES & YES & YES & YES & YES & YES \\
Observations & 1,411 & 1,411 & 1,411 & 1,411 & 1,411 & 1,411 \\
Number of countries & 73 & 73 & 73 & 73 & 73 & 73 \\
\hline$\chi^{2}$ & $2763^{* * *}$ & $845.5^{* * *}$ & $405.0^{* * *}$ & $1220^{* * *}$ & $1274^{* * *}$ & $969.5^{* * *}$ \\
AR(1) & {$[0.00]$} & {$[0.00]$} & {$[0.00]$} & {$[0.00]$} & {$[0.00]$} & {$[0.00]$} \\
& $-3.755^{* * *}$ & $-2.909^{* * *}$ & $-2.664^{* * *}$ & $-3.543^{* * *}$ & $-3.869^{* * *}$ & $-3.599^{* * *}$ \\
AR(2) & {$[0.00]$} & {$[0.00]$} & {$[0.01]$} & {$[0.00]$} & {$[0.00]$} & {$[0.00]$} \\
& 2.122 & 0.886 & 0.979 & 0.774 & 0.709 & 1.342 \\
& {$[0.03]$} & {$[0.37]$} & {$[0.33]$} & {$[0.44]$} & {$[0.48]$} & {$[0.18]$} \\
\hline \hline
\end{tabular}

Note: Heteroskedasticity and autocorrelation robust standard errors in parentheses; $p$-values in brackets. Instruments are restricted to 2 lags to minimize instrument count. Endogenous variable is the lagged dependent variable. First order serial correlation in first-differenced residuals (AR(1) significant) with no second order serial correlation $(\operatorname{AR}(2)$ insignificant) supports the claim that instruments for the SystemGMM models are valid. *, ${ }^{* *}$ and ${ }^{* * *}$ indicate significance at $10 \%, 5 \%$ and $1 \%$ level, respectively. 